\title{
Assessment of Groundwater Mineralization Processes in Mbakaou Area (Adamawa Plateau - Cameroon), by Using Conventional Diagrams and Multivariate Statistical Analysis
}

\author{
Adoua Kopa Njueya, Arnaud Zebaze Tonang, Lucas Kengni, Emile Temgoua, \\ David Guimolaire Nkouathio, and Stéphanie Dannou Chezie
}

\section{ABSTRACT}

\begin{abstract}
Management of groundwater require knowing their qualities and hydrogeochemical processes whereby these waters acquire their mineralization. The population of Mbakaou in Adamawa Plateau consumes groundwater from a doubtful quality water supply structures (wells, boreholes and catchments). This study was carried out to highlight groundwater quality and processes that govern water mineralization. So, to achieve this, 11 water samples were analyzed (1 rain water, 1 well, 3 springs and 6 boreholes). After analyzing the samples and comparing the obtained values to World Health Organization (WHO) standards, multivariate statistical analysis including Principal Component Analysis (PCA) were applied. Results show that these waters samples are fresh, generally of good quality compared to WHO standards and weakly mineralized ( 35 to $247.9 \mathrm{mg} / \mathrm{l}$ ), due to the short residence time. Calcium and magnesium bicarbonate facies is the main water type. Nitrates are the most common pollutants and reveal high vulnerability of saprolite aquifer than fractured aquifer. The groundwater mineralization is influenced by precipitation, base ion exchange process, anthropogenic activities and water-rock interaction through silicate weathering. The PCA analysis yielded three factors that explained $89.33 \%$ of the total variance. Factor 1 $(62.60 \%)$, factor $2(15.54 \%)$ and factor $3(11.19 \%)$ made respectively the difference between water samples influenced by precipitation or water rock interaction from those influenced by both water-rock interaction with precipitation or anthropogenic activities and those for water rock interaction with ion exchange process.
\end{abstract}

Keywords: Aquifer vulnerability, Hydrogeochemistry, Principal Component Analysis, Adamawa.
Published Online: February 23, 2021

ISSN: $2684-446 \mathrm{X}$

DOI :10.24018/ejgeo.2021.2.1.115

\section{A. Kopa Njueya*}

Department of Earth Sciences, Faculty of Sciences, University of Dschang, Cameroon.

(e-mail: njuedou@yahoo.fr)

A. Tonang Zebaze

Department of Earth Science, Faculty of Sciences, University of Ngaoundéré, Cameroon.

(e-mail: tonangarnaudz ${ }^{\circledR}$ yahoo.fr)

L. Kengni

Department of Earth Sciences, Faculty of Sciences, University of Dschang, Cameroon.

(e-mail: 1kengni@yahoo.fr)

E. Temgoua

Department of Soil Sciences, Faculty of Agronomy and Agricultural Sciences, University of Dschang, Cameroon.

(e-mail: etemgoua1 ${ }^{@}$ yahoo.com)

D. G. Nkouathio

Department of Earth Sciences, Faculty

of Sciences, University of Dschang,

Cameroon.

(e-mail: nkouathio@yahoo.fr)

S. Dannou Chezie

Department of Earth Sciences, Faculty

of Sciences, University of Dschang,

Cameroon.

(e-mail: dannou89@yahoo.fr)

*Corresponding Author

\section{INTRODUCTION}

Groundwaters are generally the primary source of water supply for the population of rural area in sub-Saharan countries in general and particularly in Cameroon. These waters are widely used as drinking potable water and for irrigational purposes, due to their relatively good quality in general [1], [2]. According to [3], groundwaters does not require rigorous treatment processes to make it suitable for usage. For this reason, many rural hydraulic programs such as the one in Mbakaou, have enabled the realization of several boreholes to facilitate access to potable water generally without chemical analyses. The lack of knowledge about groundwater quality in terms of physico-chemical properties does not facilitate water management. To manage groundwater resources and promote the development of rural areas, it is important to know the quality and hydrogeochemical processes that influence water mineralization from the atmosphere to aquifers. Generally, groundwaters comes from rainwater infiltration. As it moves, this water passes through unsaturated to saturated zones and its quality changes due to various processes, including leaching, precipitation, ion exchange, water-rock interaction and anthropogenic activities [4]-[7]. When the natural recharge of aquifers by rain occurs rapidly, the transport of given pollutants from the surface to unconfined 
aquifers is eased, causing the deterioration of the groundwater quality. However, this can also affect confined aquifers if its structure allows communication with unconfined aquifers. This context therefore justify why it is important to know the rainwater quality and also why it should be compared to the groundwater in an area where the recharge is made by infiltration. This helps to understand and better explain processes controlling the geochemical evolution of the groundwater in Mbakaou. To achieved this, combination of conventional diagrams (bivariate, Piper, Chadha's and Gibbs) and multivariate statistical analysis through the principal component analysis (PCA) is a useful tool that have been successfully used by many authors [3], [5], [8]-[10] to define and understand the hydrogeochemical processes that influence groundwater quality and sources of pollution. PCA enables to show the differences among physico-chemical parameters at different poles that explains mineralization processes. This study is the first in this locality that intends to assess water evolution from rain to aquifer and proposed mechanism by which water mineralization occurs using both conventional diagrams and multivariate statistical analysis.

\section{MATERIALS AND METHODS}

\section{A. Study Area}

Mbakaou which is located in the Adamawa Region, about $33 \mathrm{~km}$ from the southeast of the Tibati city, is well known for its reservoir dam built on the Djerem river in 1969. The study area (Fig. 1) extends between latitudes $6^{\circ} 15^{\prime} \mathrm{N}$ to $6^{\circ} 23^{\prime} \mathrm{N}$, and longitudes $12^{\circ} 44^{\prime} 30^{\prime \prime} \mathrm{E}$ to $12^{\circ} 50^{\prime} \mathrm{E}$. The altitudes of the area vary between 800 and $880 \mathrm{~m}$ with an average of $840 \mathrm{~m}$. Some permanent or intermittent rivers flow in the large and flat slightly incised valleys. The presence of the Mbakaou dam with a size of about 189.48 $\mathrm{Km}^{2}$ has modified the former hydrographic regime of the area. The hydrographic network is very dense, subdendritic, and is made of streams from order 1 to order 4 . It is marked at some places by straight portions and numerous waterfalls, which indicate a structural control in the study area. The area has a humid tropical climate, hot and humid, with two distinct seasons. The average annual rainfall is $1908 \mathrm{~mm}$ with an average temperature of about $23{ }^{\circ} \mathrm{C}$. The vegetation consists mainly of shrub savannah, which is evolving towards grasslands under the action of bushfires and overgrazing. Some gallery forests remain along rivers. Economically, there is no manufactory industry and income generating activities are farming, fishing and business. Field observations show that there are poor sanitation systems with construction of single pit toilet (with depth of about 5 $\mathrm{m})$ by the population who are the ones in charge of waste management [11].

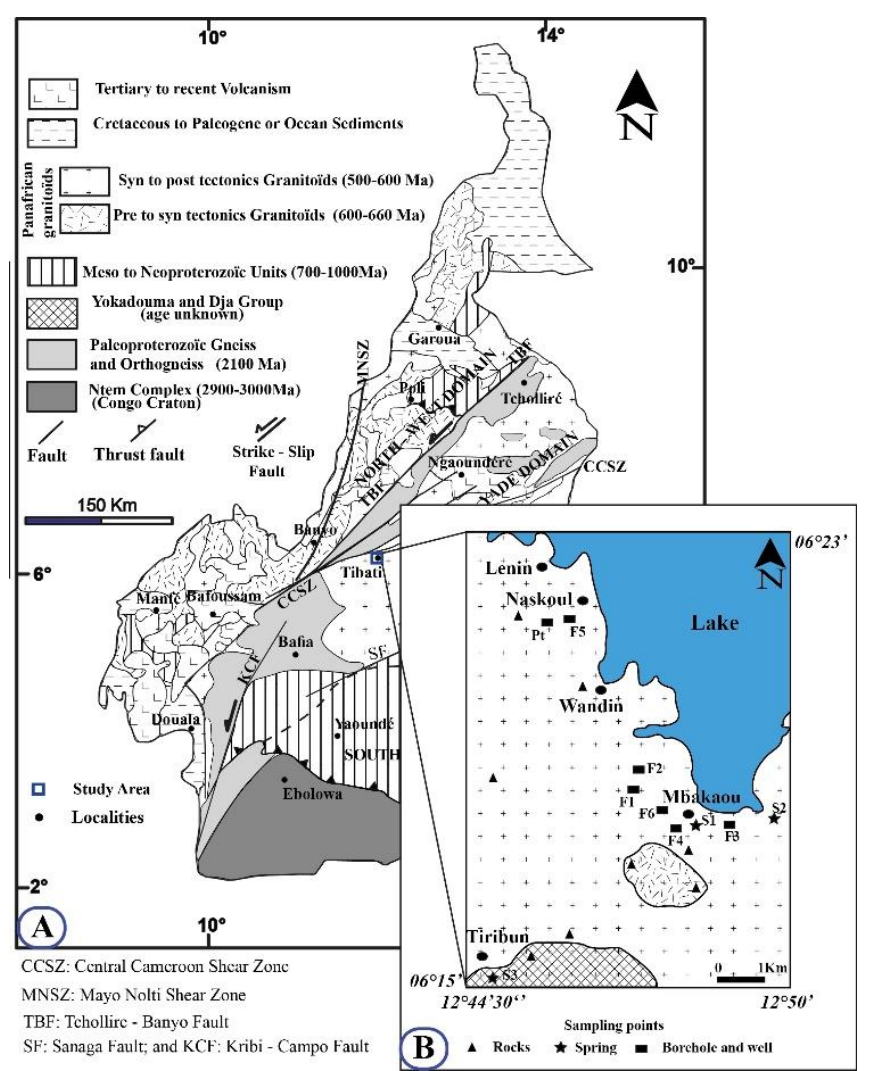

Fig. 1. Location of study area (A) on geological map of Cameroon and (B) on geological map of study area with different sampling points. (Redrawn from [12] and [13])

Geologically, this area is located on the central domain of Panafrican fold belt in Cameroon (Fig. 1) and characterized structurally by the presence of a megastructure called the Tibati Shear Zone (TSZ), known as the southern extension of the Central Cameroon Shear Zone (CCSZ, [14]). Depending on the stage of deformation, the rocks of the study area can be classified as pre-tectonic, syn-tectonic or post-tectonic granitoïds [12], [15]. The rocks found on the field are fine grain granite, medium grain granite, and porphyroïd granite. All these samples outcrops in slabs and blocks next to the Mekay river bridge, in form of blocks in the Djerem river bed, precisely next to the Mbakaou quarry (located southwest of the study area). The mineralogical composition of these granite include quartz, plagioclase, megacrysts of K-feldspar, hornblende, biotite, and accessory minerals such as sphene and oxides. The textures of these rocks are magmatic heterogranular to granoblastic. [16] and [17] shows that plagioclases are zoned in ranged an 15-23; K-feldspar are rich in Or89; Hornblende and biotite with $\mathrm{XMg}$ ranging from 0.47 to 0.58 . Mineral chemistry of the whole rocks shows that the proportion of $\mathrm{K}_{2} \mathrm{O}$ is greater than that of $\mathrm{Na}_{2} \mathrm{O}$, also the proportion of $\mathrm{CaO}$ is greater than that of $\mathrm{MgO}$ [16], [17].

Adamawa plateau is stretching in predominantly $\mathrm{N} 70^{\circ} \mathrm{E}$ direction [13], [16]. Some significant fracturing with variable directions and extensions are observed on the rocks. In the field, these formations are highly altered and, in some places, slightly covered by thick banks of alluviums drained by the Djerem river. The outcrops are located in the watercourse bed. There are also some rare preferential orientations of feldspar mega-crystals. Three different types of soils developed over granite and orthogneiss are generally 
found in the Adamawa plateau: evolved soils, indurated lateritic soils and hydromorphic soils [18], [19]. Lateritic soils (most represented) are rich in residual clays represented in order of abundance by kaolinite, phlogopite, goethite, hematite, halloysite, illite and smectite [18], [19]. Kaolinites are more present on top of the soil profile while illite and smectite are more present at the bottom. According to [19], alkaline and alkaline earths contents are completely leached from bottom to surface in Adamawa plateau rocks weathered products.

Geomorphological context of Mbakaou area shows a plain with a gentle landscape and a slight dissection model known as the Djerem plain. The course of the great collector Djerem river and its tributaries follows in most cases the major tectonic features. The Adamawa Plateau is known as the main water tower of Cameroon, particularly due to the abundance of streams and rivers in the region, as observed at Mbakaou. The most important factor that promotes infiltration and groundwater recharge is the peneplain relief. The thickness of the weathered layer is on average of $15 \mathrm{~m}$ and represents an important source of alimentation for the deep aquifers of the area [11], [20]. The fact that springs, wells and boreholes are found in the area are evidences of the availability of groundwater resources [20]. Finally, the Mbakaou artificial lake itself constitutes a big reservoir for groundwater supply in the whole region [11]. Hydrogeological studies carried out by [11], [20] and [21], highlight superficial aquifers located between 2 and $17 \mathrm{~m}$ and fractured aquifers located between 11 and $74 \mathrm{~m}$, with resistivity ranged from 50 to $671 \Omega . \mathrm{m}$. The boreholes have yields varying between 2.80 and $5.14 \mathrm{~m}^{3} / \mathrm{h}$. Transmissivity and permeability range from $10^{-6}$ to $10^{-5} \mathrm{~m}^{2} / \mathrm{s}$ and from $10^{-7}$ to $10^{-6} \mathrm{~m} / \mathrm{s}$ respectively, indicating that aquifers are semipermeable. The waters are of good quality compared to WHO standards [22], and weakly mineralized (35 to $247.9 \mathrm{mg} / \mathrm{l}$ ) with calcium and magnesium bicarbonate facies. According to these authors, water mineralization is influenced by water-rock interaction through silicate weathering [21].

\section{B. Sampling and Analytical Methods}

A total of eleven water samples (1 from rain water, 1 open well, 3 springs and 6 boreholes) were collected and analyzed in collaboration with three laboratories (Centre Pasteur of Yaoundé, Laboratory of water analysis at geological research and mining institute of Yaoundé and laboratory of soil analysis and environmental chemistry of the faculty of agronomy and agricultural science of University of Dschang). Two samples per point were collected into $500 \mathrm{ml}$ of polyethylene bottles after rinsing at least three times with water to be sampled. Concerning water samples from boreholes, it was pumped up to $5 \mathrm{~min}$ to purge aquifers before the sampling operation. During sample collection, care was taken, and standard procedure was applied to avoid contamination. Sampling points were recorded by means of GPS (Garmin etrex-30) and plotted on a map (Fig. 1). Samples locations with aquifer characteristics are resumed in Table 1. The first sample at each point was used for cations analysis and preserved with acid $\left(2 \mathrm{ml}\right.$ of $\mathrm{HNO}_{3}$ ), while second sample was used for anions analysis, with no acid. These samples were then stored and refrigerated in the laboratory until analyses were conducted.

Physicochemical parameters of water including $\mathrm{pH}$, conductivity, temperature and dissolved oxygen were determined in situ using a portable multiparameter (Waterproof-test) probe calibrated with standard solutions.

TABLE 1: LOCATION AND AQUIFER CHARACTERISTICS OF SAMPLING

\begin{tabular}{|c|c|c|c|c|c|c|}
\hline \multicolumn{7}{|c|}{ POINTS } \\
\hline \multirow{2}{*}{\multicolumn{2}{|c|}{ Samples }} & \multicolumn{3}{|c|}{ Coordinates } & \multirow{2}{*}{$\begin{array}{l}\text { Type } \\
\text { of } \\
\text { aquifer }\end{array}$} & \multirow{2}{*}{$\begin{array}{c}\text { Water } \\
\text { Depth } \\
(\mathrm{m})\end{array}$} \\
\hline & & Longitude & Latitude & $\begin{array}{l}\text { Alt. } \\
(\mathrm{m})\end{array}$ & & \\
\hline \multirow{3}{*}{ 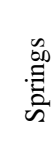 } & $\mathrm{S}_{1}$ & $12^{\circ} 48^{\prime} 23.00^{\prime \prime}$ & $06^{\circ} 17^{\prime} 51.33^{\prime \prime}$ & 836 & \multirow{4}{*}{ 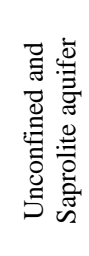 } & - \\
\hline & $\mathrm{S}_{2}$ & $12^{\circ} 49^{\prime} 43.49^{\prime \prime}$ & $06^{\circ} 18^{\prime} 00.31^{\prime \prime}$ & 863 & & - \\
\hline & $\mathrm{S}_{3}$ & $12^{\circ} 44^{\prime} 56.43^{\prime \prime}$ & $06^{\circ} 15^{\prime} 09.20^{\prime \prime}$ & 868 & & - \\
\hline$\overline{0}$ & $\mathrm{Pt}$ & $12^{\circ} 45^{\prime} 52.38^{\prime}$, & $06^{\circ} 21^{\prime} 24.73^{\prime \prime}$ & 847 & & 12 \\
\hline \multirow{6}{*}{$\begin{array}{l}\frac{a}{0} \\
\frac{0}{0} \\
\frac{0}{0} \\
0\end{array}$} & $\mathrm{~F}_{6}$ & $12^{\circ} 47^{\prime} 49.30^{\prime \prime}$ & $06^{\circ} 18^{\prime} 06.55^{\prime \prime}$ & 846 & \multirow{6}{*}{ 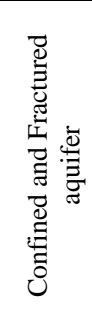 } & $\begin{array}{l}15-21 \\
35-38\end{array}$ \\
\hline & $\mathrm{F}_{5}$ & $12^{\circ} 46^{\prime} 15.38^{\prime}$ & $06^{\circ} 21^{\prime} 29.63$ ', & 855 & & - \\
\hline & $\mathrm{F}_{4}$ & $12^{\circ} 48^{\prime} 03.78^{\prime \prime}$ & $06^{\circ} 17^{\prime} 46.45^{\prime \prime}$ & 827 & & $\begin{array}{l}48-51 \\
55-60\end{array}$ \\
\hline & $\mathrm{F}_{3}$ & $12^{\circ} 48^{\prime} 58.44^{\prime \prime}$ & $06^{\circ} 17^{\prime} 50.52^{\prime}$ & 856 & & - \\
\hline & $\mathrm{F}_{2}$ & $12^{\circ} 47^{\prime} 26.10^{\prime \prime}$ & $06^{\circ} 18^{\prime} 49.64^{\prime \prime}$ & 849 & & $\begin{array}{l}11-14 \\
41-53\end{array}$ \\
\hline & $\mathrm{F}_{1}$ & $12^{\circ} 47^{\prime} 21.39^{\prime \prime}$ & $06^{\circ} 18^{\prime} 28.50^{\prime \prime}$ & 854 & & $\begin{array}{l}56-61 \\
67-74\end{array}$ \\
\hline
\end{tabular}

Hydrochemical composition of water samples concerning major elements like cations $\left(\mathrm{Ca}^{2+}, \mathrm{Mg}^{2+}, \mathrm{Na}^{+}, \mathrm{K}^{+}\right.$and $\left.\mathrm{Fe}^{2+}\right)$ and anions $\left(\mathrm{Cl}^{-}, \mathrm{NO}_{3}^{-}, \mathrm{SO}_{4}{ }^{2-}\right.$ and $\left.\mathrm{HCO}_{3}^{-}\right)$were determined in the laboratory and table 2 summarizes different methods and indicators used for their determination.

TABLE 2: DIFFERENT METHODS USED FOR PHYSICOCHEMICAL PARAMETER ANALYSIS OF WATER SAMPLE

\begin{tabular}{|c|c|c|}
\hline Indicator & Methods & $\begin{array}{c}\text { Parameter } \\
\text { designation }\end{array}$ \\
\hline Systronic-371 & Water analyzer & $\begin{array}{l}\text { Total Dissolved } \\
\text { Solids }\end{array}$ \\
\hline $\begin{array}{l}\text { Eriochrome } \\
\text { black-T }\end{array}$ & $\begin{array}{l}\text { Complexometric } \\
\text { EDTA }\end{array}$ & Total hardness \\
\hline $\begin{array}{l}\text { Eriochrome } \\
\text { murexide }\end{array}$ & & $\begin{array}{l}\text { Calcium } \\
\text { hardness }\end{array}$ \\
\hline Methyl-orange & Titrimetric method & $\begin{array}{l}\text { Carbonate and } \\
\text { Bicarbonate }\end{array}$ \\
\hline $\mathrm{K}_{2} \mathrm{CrO}_{4}$ & $\begin{array}{l}\text { Argentometric } \\
\text { method } \\
\text { Atomic }\end{array}$ & $\begin{array}{c}\text { Chloride } \\
\text { concentration }\end{array}$ \\
\hline Brucine & $\begin{array}{c}\text { Absorption } \\
\text { Spectrophotometry }\end{array}$ & Nitrate $\left(\mathrm{NO}_{3}\right)$ \\
\hline \multirow[t]{2}{*}{ Turbidimetric } & Flame photometry & $\begin{array}{l}\text { Sulfate }\left(\mathrm{SO}_{4}\right) \\
\text { Sodium } \\
\text { Potassium }\end{array}$ \\
\hline & $\begin{array}{l}\text { Calculated from } \\
\text { total hardness and } \\
\text { Calcium hardness }\end{array}$ & Magnesium \\
\hline
\end{tabular}

The quality of the investigated water samples for drinking purposes was assessed in comparison with the WHO standards. In order to perform the chemical analyses and some graphical representation (Piper and Gibbs diagrams), open software such as "DIAGRAMMES" version 5.3 were used. To identify different water types and hydrochemical processes, Chadha's diagram was used and created by Ms Excel spreadsheet. To represent this diagram, data was converted to percentage values (milli-equivalent percentages) and expressed as the difference between 
alkaline earths $(\mathrm{Ca}+\mathrm{Mg})$ and alkali metals $(\mathrm{Na}+\mathrm{K})$ for cations plotted on $\mathrm{X}$-axis, and the difference between weak acidic anions $\left(\mathrm{HCO}_{3}+\mathrm{CO}_{3}\right)$ and strong acidic anions $\left(\mathrm{Cl}+\mathrm{SO}_{4}\right)$ plotted on $\mathrm{Y}$-axis. The resulting field of study is a square or a rectangle that indicated in each of the four quadrants of the graph, the hydrochemical processes [23]. These are broadly brief as: recharging water $(\mathrm{Ca}-\mathrm{Mg}-$ $\mathrm{HCO}_{3}$-type), reverse ion exchange water ( $\mathrm{Ca}-\mathrm{Mg}-\mathrm{Cl}$-type), seawater/end-member waters (Na-Cl-type), and base ion exchange water $\left(\mathrm{Na}-\mathrm{HCO}_{3}\right.$-type).

Multivariate statistical analyses were performed using Statistica 7.0 software to make a correlation between chemical parameters and determine the principal component analysis (PCA). PCA is important to display a complex relationship among many variables and their hydrogeochemistry roles [1], [4], [5]. It is also used to distinguish different groups of samples in terms of similarities of their origin and processes that govern their mineralogy. This technique was applied on 13 variables and 11 observations. Data have been standardized as required for statistical procedures and different variables were reduced and centred to a few factors that could be interpreted as new variables. Before obtaining these factors, we extracted eigenvalues and eigenvectors of the correlation matrix [1], [6], [10], [24]. The eigenvalues are a key to choose the number of factors used to explain hydrochemical processes that define groundwater quality. Then, an eigenvalue equal or greater than 1 indicates all principal components to adopt according to Kaiser criterion [1], [6], [10], [24]. We also add another criterion to the latter that consisted of conserving all factors with total sums of variance equal or greater than $70 \%$ [3], [9].

\section{RESULTS AND DISCUSSION}

\section{A. Hydrogeochemical Characterization}

Analytical results of rain, springs, well and boreholes waters have been summarized in Table 3 . In general, the
Electrical Conductivity (EC), increases from rain $(6.20 \mu \mathrm{S} / \mathrm{cm})$ to boreholes $(249.2 \mu \mathrm{S} / \mathrm{cm})$. The $\mathrm{pH}$ level of rainwater to groundwater ranges from 5.3 (acidic) to 7.3 (neutral). Cations concentrations in all water samples (comprise between 0.1 and $36 \mathrm{mg} / \mathrm{l}$ ), are below the WHO standards. $\mathrm{Ca}^{2+}$ (in $\mathrm{Pt}, \mathrm{S}_{3}, \mathrm{~F}_{1}, \mathrm{~F}_{2}$ and $\mathrm{F}_{3}$ ) and $\mathrm{Na}^{+}$(in $\mathrm{Pt}, \mathrm{S}_{1}$, $\mathrm{S}_{2}$, and $\mathrm{F}_{5}$ ) are the most abundant cations. In many cases, the highest values were obtained in boreholes samples. The order of abundance is as follows: $\mathrm{Ca}^{2+}>\mathrm{Na}^{+}>\mathrm{Mg}^{2+}>\mathrm{K}^{+}$. Anions concentrations in most water samples $(0.02$ to $195.2 \mathrm{mg} / \mathrm{l}$ ), are dominated by $\mathrm{HCO}_{3}{ }^{-}$which are low (13.4 to $20.7 \mathrm{mg} / \mathrm{l})$ in the well and springs, but high (41.5 to 195.2 $\mathrm{mg} / \mathrm{l})$ in boreholes. The order of abundance of other anions were $\mathrm{NO}_{3}^{-}(0.0-13.7 \mathrm{mg} / \mathrm{l}), \mathrm{SO}_{4}{ }^{2-}(0.52-9.7 \mathrm{mg} / \mathrm{l})$ and $\mathrm{Cl}^{-}$ $(0.02-0.56 \mathrm{mg} / \mathrm{l})$. Nitrates $\left(\mathrm{NO}_{3}{ }^{-}\right)$are present in the well, springs and some boreholes $\left(\mathrm{F}_{4}, \mathrm{~F}_{5}\right.$ and $\left.\mathrm{F}_{6}\right)$ but relatively absent in others $\left(F_{1}, F_{2}\right.$ and $\left.F_{3}\right)$. All anions concentrations values (excepted nitrates) are higher in boreholes than in water samples from springs and well. These anions concentration values are lower than the WHO standard limits. These results confirm the evolution of the water mineralization which is function of the residence time, lithological nature of the aquifer and human activities [9], [25]. Comparison between mineralization value of rainwater with springs or well on the one hand and rainwater with boreholes on the other hand, shows that the residence time of the groundwater in boreholes is greater than groundwater of springs or well.

This result is in agreement with those along the Cameroon Line where many authors [26]-[28] argue that low mineralization of groundwaters (less than $500 \mathrm{mg} / \mathrm{l}$ ) is due to the short residence time and fast flowing water. The fact that the contents of alkalis and alkaline earths metals increase from groundwater of saprolite aquifers to groundwater of fractured aquifers in general, reveal the intense leaching that occurs and confirms the previous study made by [18] and [19].

TABLE 3: PHYSICOCHEMICAL ANALYSIS AND CHLORO-ALKALINE INDEX (CAI) OF WATER SAMPLE IN THE STUDY AREA

\begin{tabular}{|c|c|c|c|c|c|c|c|c|c|c|c|c|c|c|c|}
\hline \multirow{2}{*}{ Sample } & \multirow{2}{*}{$\mathrm{pH}$} & \multirow{2}{*}{$\begin{array}{c}\mathrm{EC} \\
\mu \mathrm{S} / \mathrm{cm}\end{array}$} & \multirow{2}{*}{$\begin{array}{l}\text { Temp } \\
\left({ }^{\circ} \mathrm{C}\right)\end{array}$} & $\mathrm{Na}^{+}$ & $\mathrm{K}^{+}$ & $\mathrm{Mg}^{2+}$ & $\mathrm{Ca}^{2+}$ & $\mathrm{Fe}^{2+}$ & $\mathrm{HCO}_{3}{ }^{-}$ & $\mathrm{SO}_{4}{ }^{2-}$ & $\mathrm{Cl}^{-}$ & $\mathrm{NO}_{3}^{-}$ & TDS & CAI1 & CAI2 \\
\hline & & & & \multicolumn{10}{|c|}{$\mathrm{mg} / \mathrm{l}$} & \multicolumn{2}{|c|}{$\mathrm{meq} / \mathrm{l}$} \\
\hline $\mathrm{R}$ & 5.60 & 6.20 & 20.30 & 0.40 & 0.20 & 0.03 & 0.10 & 0.00 & 7.00 & 0.00 & 0.01 & 0.00 & 7.74 & -38.97 & -0.19 \\
\hline $\mathrm{Pt}$ & 5.50 & 13.50 & 25.20 & 2.06 & 1.40 & 1.20 & 2.10 & 0.35 & 15.80 & 1.40 & 0.06 & 11.20 & 35.60 & -73.23 & -0.43 \\
\hline $\mathrm{S}_{2}$ & 5.71 & 11.60 & 25.60 & 0.98 & 0.50 & 0.10 & 0.10 & 0.47 & 20.70 & 0.00 & 0.14 & 0.00 & 23.10 & -13.06 & -0.15 \\
\hline $\mathrm{S}_{1}$ & 5.60 & 15.30 & 25.90 & 2.66 & 1.40 & 1.30 & 1.80 & 0.73 & 13.40 & 1.19 & 0.04 & 10.90 & 33.50 & -133.50 & -0.62 \\
\hline $\mathrm{F}_{6}$ & 5.65 & 43.00 & 27.40 & 1.84 & 4.30 & 1.30 & 2.30 & 0.56 & 41.50 & 1.23 & 0.02 & 13.70 & 66.80 & -336.71 & -0.27 \\
\hline $\mathrm{F}_{5}$ & 5.25 & 35.60 & 27.90 & 3.88 & 0.40 & 0.10 & 0.50 & 0.09 & 36.60 & 0.00 & 0.11 & 9.98 & 51.60 & -56.75 & -0.29 \\
\hline $\mathrm{F}_{4}$ & 5.78 & 61.50 & 26.30 & 1.84 & 5.50 & 2.60 & 1.70 & 0.15 & 61.00 & 0.66 & 0.07 & 10.90 & 84.50 & -111.09 & -0.22 \\
\hline $\mathrm{F}_{3}$ & 7.22 & 214.00 & 27.40 & 10.60 & 3.80 & 9.20 & 18.60 & 0.30 & 185.10 & 0.52 & 0.56 & 0.00 & 228.80 & -34.39 & -0.18 \\
\hline $\mathrm{F}_{2}$ & 7.31 & 249.20 & 27.20 & 3.48 & 4.20 & 1.10 & 36.00 & 0.00 & 195.20 & 7.70 & 0.20 & 0.00 & 247.90 & -44.97 & -0.08 \\
\hline$F_{1}$ & 7.23 & 244.70 & 27.50 & 3.50 & 5.00 & 1.10 & 36.00 & 0.10 & 189.10 & 9.70 & 0.40 & 0.00 & 244.90 & -23.88 & -0.08 \\
\hline $\begin{array}{l}\text { WHO } \\
(2006)\end{array}$ & $\begin{array}{c}6,5- \\
8,5\end{array}$ & 750 & I & 200 & 100 & 30 & 75 & $<0,3$ & 200 & 250 & 200 & 10 & & & \\
\hline
\end{tabular}

Two groups of facies ([29]) were identified in the Mbakaou area (Fig. 2a):

- Calci-magnesian bicarbonate $\left(\mathrm{Ca}-(\mathrm{Mg})-\mathrm{HCO}_{3}\right)$ facies which grouped majority of water samples from springs and well $\left(\mathrm{Pt}, \mathrm{S}_{1}\right.$, and $\left.\mathrm{S}_{3}\right)$ and those from boreholes $\left(\mathrm{F}_{1}, \mathrm{~F}_{2}, \mathrm{~F}_{3}, \mathrm{~F}_{4}\right.$, and $\left.\mathrm{F}_{6}\right)$;
- Sodic and potassic bicarbonate $\left(\mathrm{Na}-(\mathrm{K})-\mathrm{HCO}_{3}\right)$ facies which are represented by water from rain $(\mathrm{R})$, spring $\left(\mathrm{S}_{2}\right)$ and borehole $\left(\mathrm{F}_{5}\right)$.

The first water facies indicates that the mineralization process is mainly influenced by the weathering of silicate [7], [26]-[28], which produces mostly $\mathrm{Ca}^{2+}$ and $\mathrm{HCO}_{3}{ }^{-}$and influences the water type. The second water facies influenced by $\mathrm{Na}^{+}$, is due to the cation exchange process [7], 
[25] which indicates the exchange of $\mathrm{Ca}^{2+}$ by $\mathrm{Na}^{+}$. Variation of facies from the atmosphere to the surface and subsurface suggests that different processes took place when rain fell, and these processes modify water composition and their mineralization.

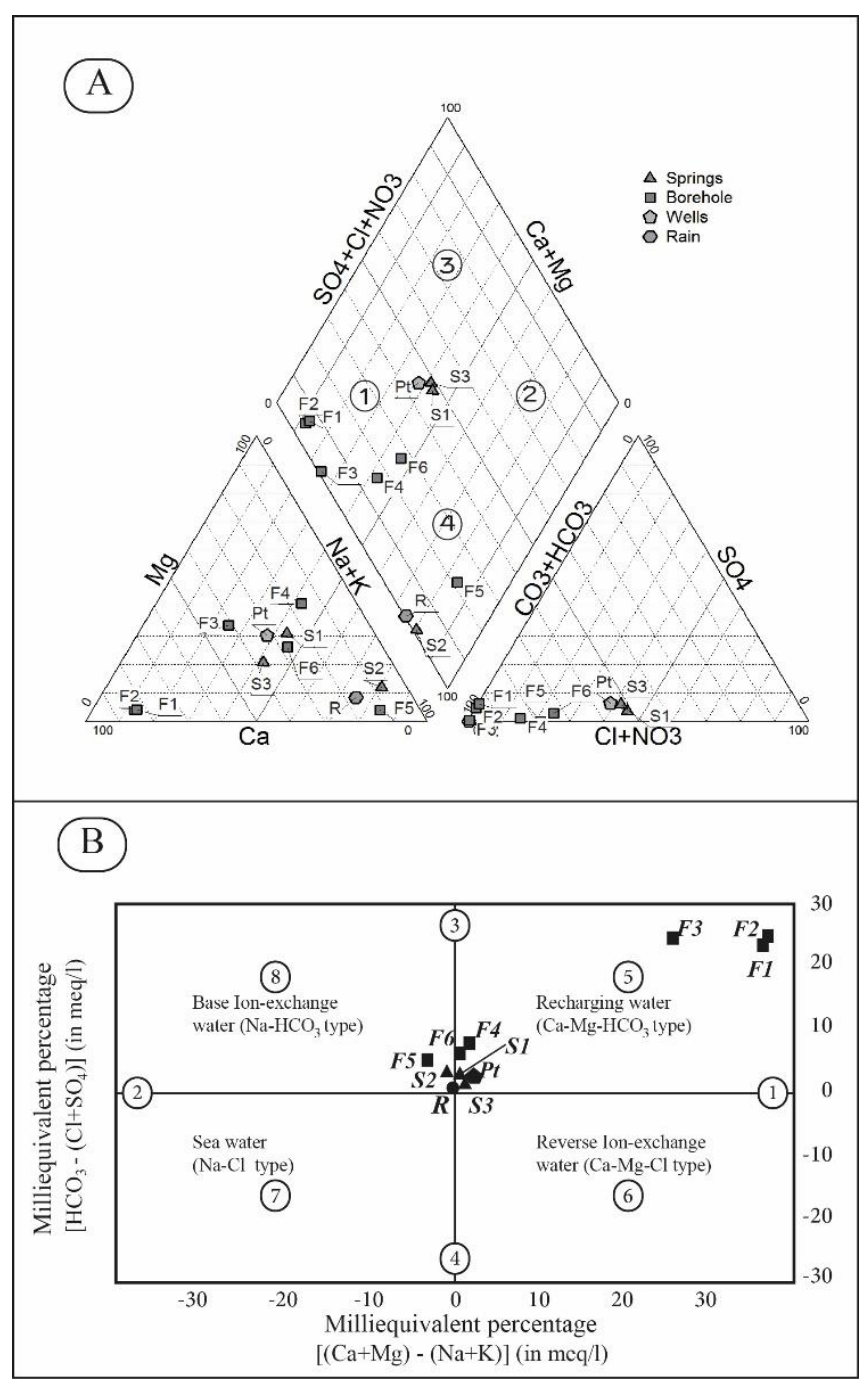

Fig. 2. Samples grouped in term of Chemical facies A) on the Piper diagram [29] and B) on the Chadha's diagram.

To confirm the results obtained from the Piper diagram, the hydrochemical diagram proposed by [23] was also applied (Fig. 2b) to identify different water types and hydrochemical processes. From this diagram, two types of waters are distinguished: the most dominant $\mathrm{Ca}-\mathrm{Mg}-$ $\mathrm{HCO}_{3}$ water type belong to the $5^{\text {th }}$ field and corresponds to recharging waters, followed by $\mathrm{Na}-\mathrm{HCO}_{3}$ water type in field 8 which is less represented and corresponds to the base ion exchange water.

These two types of waters confirm results obtained from the Piper diagram. The most dominant facies observed in this area shows that alkaline earths metals and weak acidic anions in water samples exceed alkali metals and strong acidic anions $\left(\mathrm{Pt}, \mathrm{S}_{1}, \mathrm{~S}_{3}, \mathrm{~F}_{1}, \mathrm{~F}_{2}, \mathrm{~F}_{3}, \mathrm{~F}_{4}\right.$ and $\left.\mathrm{F}_{6}\right)$ respectively. The second facies shows that alkali metals and weak acidic anions in water samples exceed alkaline earths and strong acidic anions respectively $\left(\mathrm{R}, \mathrm{S}_{2}\right.$ and $\left.\mathrm{F}_{5}\right)$. Recharging waters are formed when water that enters into the ground from the surface, carries dissolved minerals that contains calcium in the form of $\mathrm{HCO}_{3}$ and the geochemically mobile $\mathrm{Ca}$.

Base ion exchange waters are less prominent in the study area, due to the normal ion exchange processes [30], [31] This result was confirmed by the chloro-alkaline index (CAI) which is computed using the following formula (1) and (2) ([32]):

$$
\begin{aligned}
& \text { CAI } 1=\left[\mathrm{Cl}^{-}-\left(\mathrm{Na}^{+}+\mathrm{K}^{+}\right)\right] / \mathrm{Cl}^{-} \\
& \text {CAI } 2=\left[\mathrm{Cl}^{-}-\left(\mathrm{Na}^{+}+\mathrm{K}^{+}\right)\right] /\left(\mathrm{SO}_{4}{ }^{2-}+\mathrm{HCO}_{3}{ }^{-}+\mathrm{NO}_{3}{ }^{-}\right)
\end{aligned}
$$

where all values are expressed in meq/l.

From these indexes, when there is a normal exchange between $\mathrm{Ca}^{2+}$ or $\mathrm{Mg}^{2+}$ in water with $\mathrm{Na}^{+}$and $\mathrm{K}^{+}$in the aquifer material, both the above indices give negative values. If these indexes give positive values, there is a reverse ion exchange i.e., exchange between $\mathrm{Na}^{+}$and $\mathrm{K}^{+}$in water with $\mathrm{Ca}^{2+}$ or $\mathrm{Mg}^{2+}$ in the aquifer matrix [32], [33]. All samples had negative CAI 1 and CAI 2 values (Table 3), indicating that the normal ion exchange prevailed over the reverse ion exchange in the aquifer matrix.

The characterization of water samples in function of factors that influence mineralization [34], reveals that we have three groups (Fig. 3).

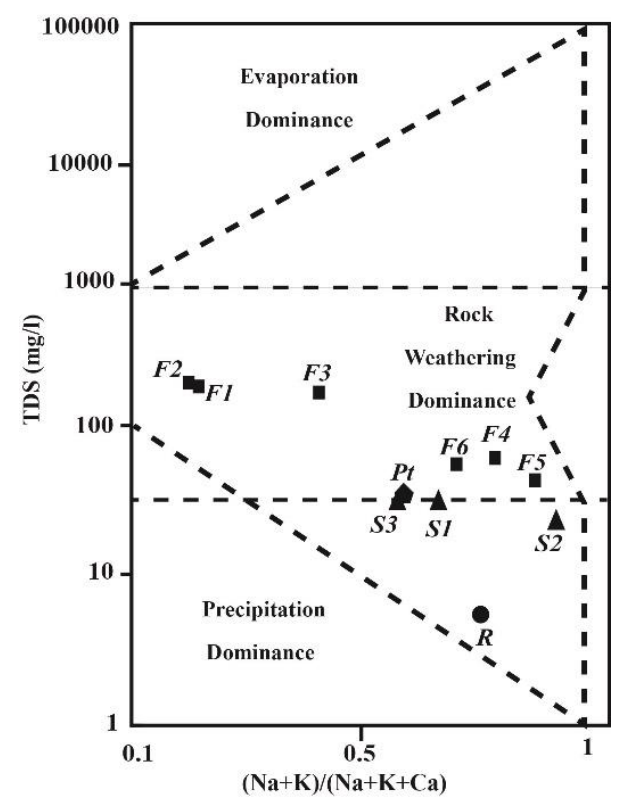

Fig. 3. Mineralization process of the analyzed waters on the Gibbs diagram.

The first group represented by water samples which are entirely influenced by the water rock interaction (WRI) through silicates weathering $\left(F_{1}, F_{2}, F_{3}, F_{4}, F_{5}\right.$ and $\left.F_{6}\right)$.

The second group represented by water samples influenced by WRI and precipitation ( $\mathrm{Pt}, \mathrm{S}_{1}$ and $\mathrm{S}_{3}$ ).

The third group represented by water samples moderately or only influenced by precipitation $\left(R\right.$ and $\left.S_{2}\right)$.

Based on the Gibbs diagram we can conclude that water mineralization in the study area, is mainly controlled by the WRI process and precipitation.

\section{B. Correlation among Variables}

Relationships between the main hydrochemical variables were evaluated using the Pearson correlation coefficient which should either be positive or negative (Table 4), and correlation diagrams (Fig. 4). 


\begin{tabular}{|c|c|c|c|c|c|c|c|c|c|c|c|c|c|}
\hline & $\mathrm{pH}$ & EC & $\mathrm{T}^{\circ} \mathrm{C}$ & $\mathrm{Na}^{+}$ & $\mathrm{K}^{+}$ & $\mathrm{Mg}^{2+}$ & $\mathrm{Ca}^{2+}$ & $\mathrm{Fe}^{2+}$ & $\mathrm{HCO}_{3}{ }^{-}$ & $\mathrm{SO}_{4}{ }^{2-}$ & $\mathrm{Cl}^{-}$ & $\mathrm{NO}_{3}{ }^{-}$ & TDS \\
\hline $\mathrm{pH}$ & 1.000 & & & & & & & & & & & & \\
\hline $\mathrm{EC}$ & 0.975 & 1.000 & & & & & & & & & & & \\
\hline $\mathrm{T}^{\circ} \mathrm{C}$ & 0.378 & 0.498 & 1.000 & & & & & & & & & & \\
\hline $\mathrm{Na}^{+}$ & 0.619 & 0.630 & 0.503 & 1.000 & & & & & & & & & \\
\hline $\mathrm{K}^{+}$ & 0.640 & 0.685 & 0.537 & 0.337 & 1.000 & & & & & & & & \\
\hline $\mathrm{Mg}^{2+}$ & 0.527 & 0.480 & 0.312 & 0.898 & 0.426 & 1.000 & & & & & & & \\
\hline $\mathrm{Ca}^{2+}$ & 0.941 & 0.961 & 0.415 & 0.438 & 0.603 & 0.255 & 1.000 & & & & & & \\
\hline $\mathrm{Fe}^{2+}$ & -0.351 & -0.427 & 0.159 & -0.053 & -0.153 & 0.066 & -0.433 & 1.000 & & & & & \\
\hline $\mathrm{HCO}_{3}{ }^{-}$ & 0.973 & 0.997 & 0.519 & 0.670 & 0.695 & 0.531 & 0.939 & -0.417 & 1.000 & & & & \\
\hline $\mathrm{SO}_{4}{ }^{2-}$ & 0.746 & 0.788 & 0.351 & 0.092 & 0.557 & -0.094 & 0.914 & -0.371 & 0.744 & 1.000 & & & \\
\hline $\mathrm{Cl}^{-}$ & 0.834 & 0.818 & 0.457 & 0.858 & 0.445 & 0.745 & 0.694 & -0.217 & 0.843 & 0.421 & 1.000 & & \\
\hline $\mathrm{NO}_{3}{ }^{-}$ & -0.677 & -0.593 & 0.159 & -0.323 & -0.076 & -0.230 & -0.595 & 0.460 & -0.591 & -0.409 & -0.622 & 1.000 & \\
\hline TDS & 0.968 & 0.997 & 0.546 & 0.659 & 0.717 & 0.520 & 0.946 & -0.390 & 0.997 & 0.767 & 0.825 & -0.540 & 1.000 \\
\hline
\end{tabular}

Based on these correlation values we can distinguish three categories of relationships:

- variables with correlation values greater than 0.70 which indicate a high correlation. Therefore, we have a high and strong positive correlation of $\mathrm{pH}$ with $\mathrm{EC}, \mathrm{Ca}^{2+}, \mathrm{HCO}_{3}{ }^{-}$, $\mathrm{SO}_{4}{ }^{2-}, \mathrm{Cl}^{-}$and TDS; $\mathrm{EC}$ with $\mathrm{Ca}^{2+}, \mathrm{HCO}_{3}{ }^{-}, \mathrm{SO}_{4}{ }^{2-}, \mathrm{Cl}^{-}$and TDS; $\mathrm{Na}^{+}$with $\mathrm{Mg}^{2+}$ and $\mathrm{Cl}^{-} ; \mathrm{K}^{+}$with TDS; $\mathrm{Mg}^{2+}$ with $\mathrm{Cl}^{-}$; $\mathrm{Ca}^{2+}$ with $\mathrm{HCO}_{3}{ }^{-}, \mathrm{SO}_{4}{ }^{2-}$ and TDS; $\mathrm{HCO}_{3}{ }^{-}$with $\mathrm{SO}_{4}{ }^{2-}, \mathrm{Cl}^{-}$and TDS; $\mathrm{SO}_{4}{ }^{2-}$ with TDS and $\mathrm{Cl}^{-}$with TDS;

- variables with correlation values ranging between 0.50 and 0.70 , which indicate a moderate correlation. According to table 4 , we have a moderate relationship which is positive (between $\mathrm{pH}$ with $\mathrm{Na}^{+}, \mathrm{K}^{+}$and $\mathrm{Mg}^{2+}$; $\mathrm{EC}$ with $\mathrm{Na}^{+}$and $\mathrm{K}^{+}$; Temperature with $\mathrm{Na}^{+}, \mathrm{K}^{+}, \mathrm{HCO}_{3}{ }^{-}$, and $\mathrm{TDS}$; $\mathrm{HCO}_{3}{ }^{-}$with $\mathrm{Na}^{+}, \mathrm{K}^{+}$and $\mathrm{Mg}^{2+} ; \mathrm{SO}_{4}{ }^{2-}$ with $\mathrm{K}^{+} ; \mathrm{Cl}^{-}$with $\mathrm{Ca}^{2+}$ ) and negative (between $\mathrm{NO}_{3}{ }^{-}$with $\mathrm{pH}, \mathrm{EC}, \mathrm{Ca}^{2+}, \mathrm{HCO}_{3}{ }^{-}, \mathrm{Cl}^{-}$and TDS);

- variables with correlation values less than 0.50 , which indicate a weak correlation like $\mathrm{Fe}^{2+}$ with other variables.

These correlation values among variables (Table 4) mean that paired variables have a strong to moderate influence on water mineralization [9]. Moreover, these correlations show that the order of contribution in water mineralization by ions is as follow: $\mathrm{HCO}_{3}{ }^{-}, \mathrm{Ca}^{2+}, \mathrm{Cl}^{-}, \mathrm{SO}_{4}{ }^{2-}, \mathrm{K}^{+}, \mathrm{Na}^{+}, \mathrm{Mg}^{2+}$ and $\mathrm{NO}_{3}{ }^{-}$. Due to low correlation between $\mathrm{Fe}^{2+}$ and TDS, $\mathrm{Fe}^{2+}$ contributes less than the other variable to the water mineralization. The strong to moderate positive relationship between major ions (excepted nitrate) implies that these ions were derived from the same source. This is supported by the positive correlation between $\mathrm{HCO}_{3}{ }^{-}$with $\mathrm{Mg}^{2+}, \mathrm{Na}^{+}, \mathrm{K}^{+}$, $\mathrm{SO}_{4}{ }^{2-}, \mathrm{Cl}^{-}$, and $\mathrm{Ca}^{2+}(\mathrm{r}=0.531, \mathrm{r}=0.670, \mathrm{r}=0.695, \mathrm{r}=$ $0.744, \mathrm{r}=0.843$ and $\mathrm{r}=0.939$, respectively) and also between $\mathrm{SO}_{4}{ }^{2-}$ with $\mathrm{K}^{+}, \mathrm{HCO}_{3}{ }^{-}$, TDS and $\mathrm{Ca}_{2}{ }^{+}(\mathrm{r}=0.557, \mathrm{r}$ $=0.744, r=0.767$, and $r=0.914$ respectively, Table 4) which suggests that weathering of rock-forming minerals is the main source that provide these ions concentration in solution [7]. Fig. 4a and $4 \mathrm{~b}$ show that all sample points are below equiline $1 / 1$. This fact confirms that WRI through silicates weathering is the main source of ions found in groundwater [31].
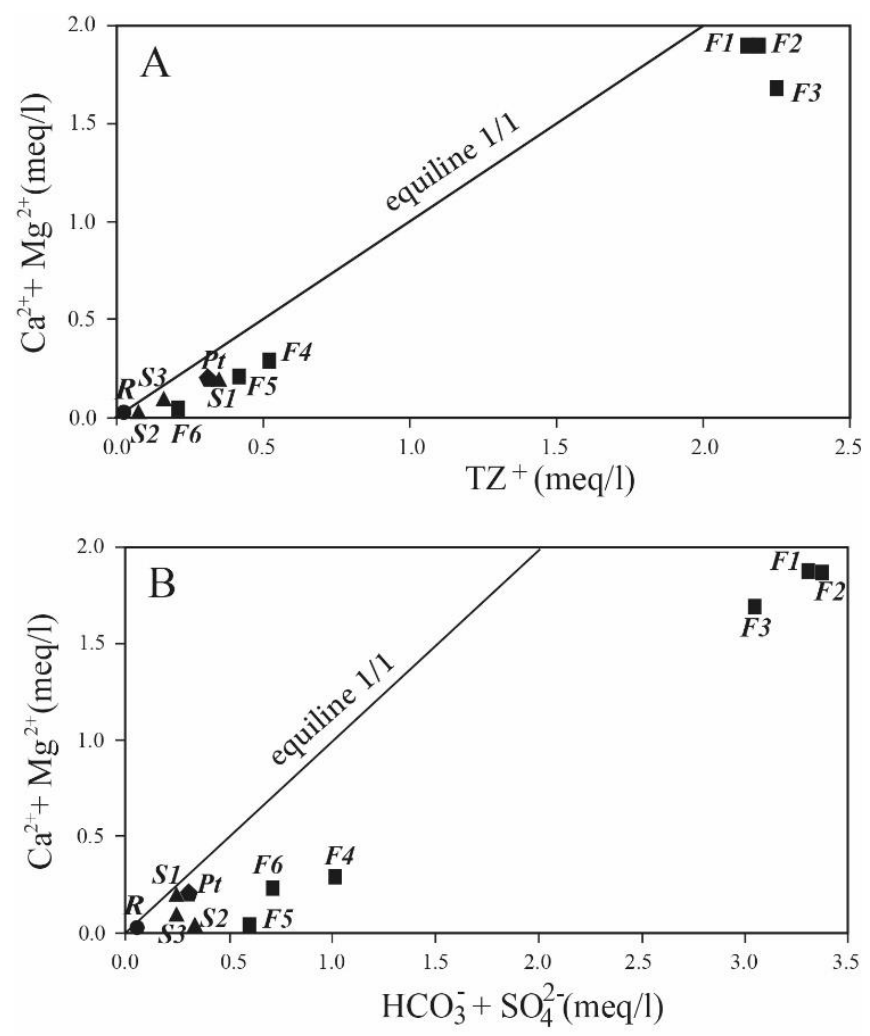

Fig. 4. Scatter diagram of $\mathrm{A})$ alkaline earths metals $\left(\mathrm{Ca}^{2+}+\mathrm{Mg}^{2+}\right)$ versus total cations $\left(\mathrm{TZ}^{+}\right)$and $\left.\mathrm{B}\right) \mathrm{Ca}^{2+}+\mathrm{Mg}^{2+}$ versus $\mathrm{HCO}_{3}{ }^{-}+\mathrm{SO}_{4}{ }^{2-}$.

Concerning nitrate, it is a soluble anion found naturally at low concentrations in precipitation, but it can be enriched to high levels in groundwater by anthropogenic activities [7], [25], [28] like agriculture in many cases. To assess the influence of agricultural practices in groundwater contamination by nitrate, a strong positive relationship should be observed between nitrate and potassium. In the present case the correlation coefficient between $\mathrm{NO}_{3}{ }^{-}$and $\mathrm{K}^{+}$showed no significant correlation $(\mathrm{r}=0.076$, Table 4) indicating that agricultural practices cannot be considered as the major source of $\mathrm{NO}_{3}{ }^{-}$in the study area. However, the moderate but negative correlation $(r=-0.622)$ (Table 4) between $\mathrm{NO}_{3}{ }^{-}$and $\mathrm{Cl}^{-}$supports input of $\mathrm{NO}_{3}{ }^{-}$by humanrelated activities which in this case can be attributed to poor sanitation conditions [6], [10], [26], [35].

\section{Principal Component Analysis (PCA)}

Analysis of the influence of different parameters in water mineralization, was performed through PCA of a dataset of 11 observations and 13 variables. According to the Kaiser criterion, three Principal Components were extracted with an eigenvalue greater than 1 (Table 5; Fig. 5), accounting 
for $89.33 \%$ of the total variance in the dataset.

TABLE 5: AMOUNT OF VARIANCE THAT EXPLAIN COMPONENTS CHOSEN

\begin{tabular}{cccc}
\hline & Eigenvalue & \% of variance & Cumul \% of variance \\
\hline PC1 & $\mathbf{8 . 1 4}$ & $\mathbf{6 2 . 6 0}$ & $\mathbf{6 2 . 6 0}$ \\
PC2 & $\mathbf{2 . 0 2}$ & $\mathbf{1 5 . 5 4}$ & $\mathbf{7 8 . 1 3}$ \\
PC3 & $\mathbf{1 . 4 5}$ & $\mathbf{1 1 . 1 9}$ & $\mathbf{8 9 . 3 3}$ \\
PC4 & 0.61 & 4.72 & 94.04 \\
PC5 & 0.48 & 3.68 & 97.72 \\
PC6 & 0.19 & 1.47 & 99.19 \\
PC7 & 0.08 & 0.60 & 99.79 \\
PC8 & 0.02 & 0.18 & 99.97 \\
PC9 & 0.00 & 0.03 & 100.00 \\
PC10 & 0.00 & 0.00 & 100.00 \\
\hline
\end{tabular}

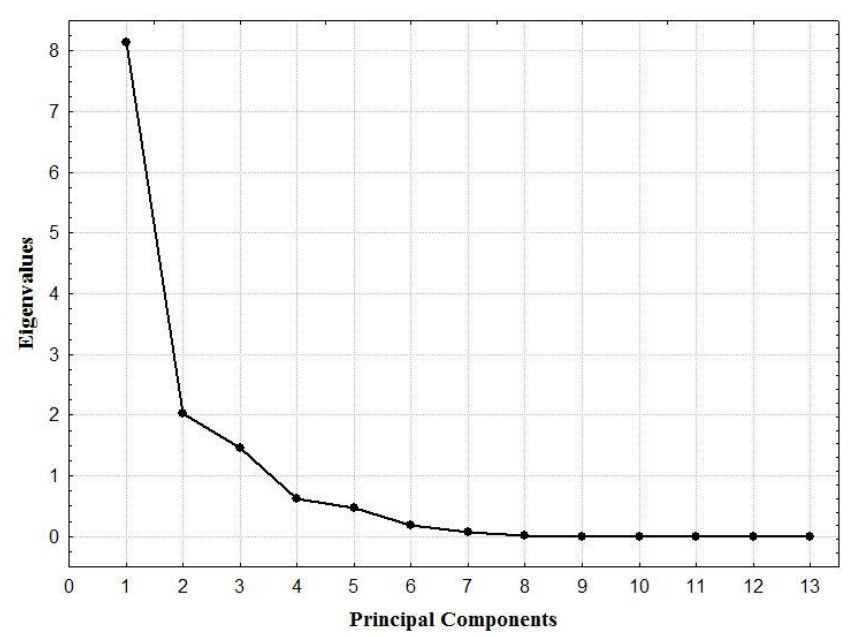

Fig. 5. Eigenvalues of Principal Components.

Component 1 (PC1) explains $62.60 \%$ of the total variance (Fig. 6). $\mathrm{PC} 1$ is characterized by a high positive loadings on eleven variables $\left(\mathrm{HCO}_{3}{ }^{-}, \mathrm{Ca}^{2+}, \mathrm{Cl}^{-}, \mathrm{SO}_{4}{ }^{2-}, \mathrm{K}^{+}, \mathrm{Na}^{+}, \mathrm{Mg}^{2+}\right.$ TDS, EC $\mathrm{pH}$ and Temperature) and negative loadings on two variables $\left(\mathrm{NO}_{3}{ }^{-}\right.$and $\left.\mathrm{Fe}^{2+}\right)$. This shows that chemical parameters correlated positively are those which highly control water mineralization in the study area [9] and concentration of these parameters are linked to the $\mathrm{pH}$ and temperature. There is association of $\mathrm{Na}^{+}$and $\mathrm{Cl}^{-}$to this PC1 and a high correlation between them (Table 4); this suggests salinization. Because there is no marine water but a lake in the study area, excess sodium observed in these samples can come from rocks weathering and leaching. Negative loading of nitrate which is on the opposite side of the other ion suggests groundwater pollution by anthropogenic activities. Then the component 1 is defined as mineralization by rock weathering process which is dominant and anthropogenic activities.

Component 2 (PC2) describes $15.54 \%$ of total variance. PC2 is characterized by a moderate positive loading of $\mathrm{SO}_{4}{ }^{2}$, and negative loading of $\mathrm{Na}^{+}, \mathrm{Mg}^{2+}$ and $\mathrm{Fe}^{2+}$. This fact confirms that these ions which contributes to water mineralization, may have different origins: WRI (by silicate weathering of ferromagnesian minerals and sodic feldspars) and anthropogenic factors [6], [9], [36].
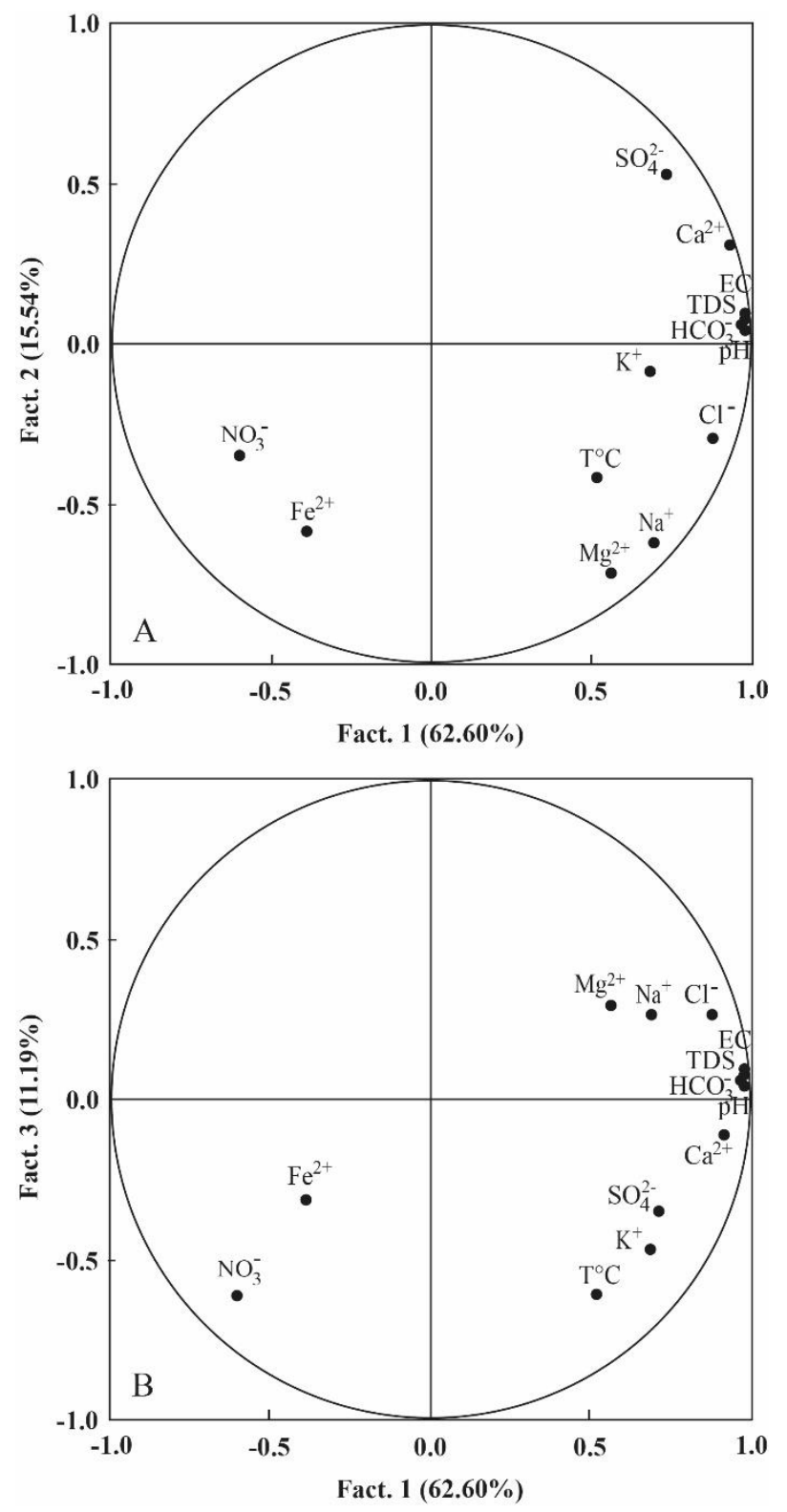

Fig. 6. Hydrochemical variables plotted on the A) F1xF2 and B) F1xF3 axis.

However, the fact that $\mathrm{Na}^{+}$with $\mathrm{Mg}^{2+}$ are highly correlated and are on opposite side with $\mathrm{Fe}^{2+}$ and $\mathrm{Ca}^{2+}$, suggests that PC2 explains the ion exchange process [1]. The origin of $\mathrm{Fe}^{2+}, \mathrm{Mg}^{2+}$ and $\mathrm{Na}^{+}$can be attributed to the hydrolysis of ferromagnesian rich minerals [26], [27] such as hornblende and biotite that are composed of basement rocks [16], [17]. $\mathrm{Na}^{+}$and $\mathrm{Ca}^{2+}$ can be attributed to the hydrolysis of plagioclase as suggested many authors along the Cameroon Line in the basement area ([26], [27] in Western Highlands of Cameroon; [28] in Mbanga, Njombe and Penja in Mungo Division; [7] in West Cameroon).

Component 3 (PC3) explains $11.19 \%$ of the total variance in water chemistry. $\mathrm{PC} 3$ has negative loading with $\mathrm{NO}_{3}{ }^{-}$and temperature. This implies that the concentration of this ion is also influenced by temperature like others. The fact that PC3 is correlated to nitrate, explains groundwater pollution by anthropogenic activities [1], [10], [24], [35]. The presence of nitrate in some groundwater may be due to leaching of $\mathrm{NO}_{3}{ }^{-}$from fertilizers or waste disposal during infiltration [24], [36]. The fact that water from some boreholes $\left(\mathrm{F}_{4}, \mathrm{~F}_{5}\right.$ and $\left.\mathrm{F}_{6}\right)$, springs $\left(\mathrm{S}_{1}\right.$ and $\left.\mathrm{S}_{3}\right)$ and well $(\mathrm{Pt})$ 
contain nitrate confirms that the water from these structures (boreholes, springs and well) are the mixture of surface water, groundwater from saprolite layer and groundwater from fractured aquifers.

Individual factor maps help to identify the contribution of water samples in the definition of different axes that constitute principal component (Fig. 7) and makes a difference between samples in function of mineralization processes.
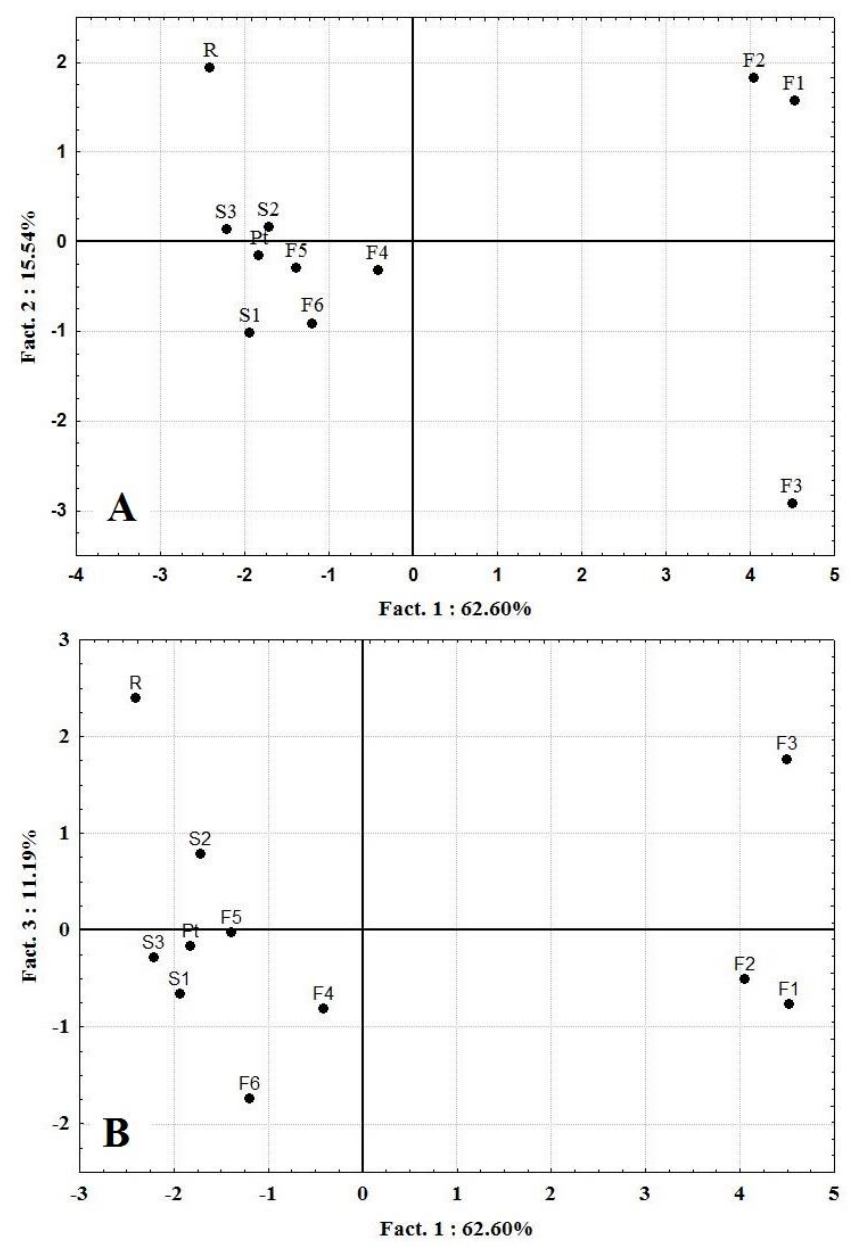

Fig. 7. Individual factor map on the $\mathrm{A}) \mathrm{F} 1 \mathrm{xF} 2$ and $\mathrm{B}$ ) $\mathrm{F} 1 \mathrm{xF} 3$ axis.

According to this individual factor map along the F1 axis, two groups are distinguished between these samples. The first group concerns water from boreholes $F_{1}, F_{2}$ and $F_{3}$ with high mineralization and mainly influenced by WRI. Second group corresponds to water samples with low mineralization, influenced by precipitation $\left(R\right.$ and $\left.S_{2}\right)$ and both processes, precipitation with WRI $\left(\mathrm{F}_{5} \mathrm{Pt}, \mathrm{S}_{3}, \mathrm{~S}_{1}, \mathrm{~F}_{4}\right.$, and $F_{6}$ ). Factors 2 and 3 allow distinguishing three groups of water samples. The first group represented by $R$ and $S_{2}$ samples are influenced by precipitation. The second group represented by samples $\mathrm{F}_{5}, \mathrm{Pt}, \mathrm{S}_{3}, \mathrm{~S}_{1}, \mathrm{~F}_{4}$, and $\mathrm{F}_{6}$, in which mineralization is influenced either by precipitation, WRI or by anthropogenic activities. The fact that water samples from boreholes belong to the same group with those from springs and well suggest the mixing of the good groundwater with the infiltration of poor water quality [10], [24]. This situation can be justified by the presence of nitrate despite the fact that water samples came from fractured aquifer. The third and last group represented by $F_{1}, F_{2}$ and
$F_{3}$, corresponds to water samples in which mineralization processes are mainly influenced by WRI through hydrolysis and the ion exchange process [10], [35].

\section{CONCLUSION}

Assessment of factors influencing water mineralization through conventional diagrams and statistical analyses in the Mbakaou area revealed that the water sources are slightly acidic to neutral. Piper and Chadha's diagrams show that two facies are represented: Calci-magnesian bicarbonate $\left(\mathrm{Ca}-(\mathrm{Mg})-\mathrm{HCO}_{3}\right)$ facies and Sodic and potassic bicarbonate $\left(\mathrm{Na}-(\mathrm{K})-\mathrm{HCO}_{3}\right)$ facies. Mineralization processes according to conventional diagrams and multivariate statistical analysis are influenced by four main processes: precipitation, water rock interaction, base ion exchange processes and anthropogenic activities. The mineralization process of some boreholes and springs are influenced by water rock interaction, mixing of rain with good groundwater which through leaching of infiltration contribute to pollution from nitrates which can be attributed to anthropogenic activities. Leaching contributes to export of alkaline and alkaline earths metals from the top of the soil profiles to the bottom and increases these ions in groundwater from saprolite to fractured aquifer.

To manage groundwater quality efficiency in Cameroon in general and in the Adamawa plateau particularly, the main pollutant which is nitrate should be used as an indicator to assess if waters from realized boreholes coming exclusively from closed fractured aquifers or if these waters are mixed with those coming from saprolite aquifers which are more vulnerable. It results from this study that conventional hydrogeochemical diagrams coupled with multivariate statistical analysis are suitable for better understanding of hydrogeochemical processes which influenced water mineralization.

\section{ACKNOWLEDGMENT}

The authors greatly appreciate comments of Editor and anonymous reviewers which help to improve the quality of paper. They also want to thank Mme Djukem Wamba Danny Love who helped in improving the language of the present manuscript.

\section{REFERENCES}

[1] M. Kumar, K. Kumari, K.U. Singh, A.L. Ramanathan, Hydrogeochemical processes in the groundwater environment of Muktsar, Punjab: conventional graphical and multivariate statistical approach. Environ. Geol., vol. 57, pp. 873-884. 2009.

[2] E.D. Sunkari, M.S. Zango, H.M. Korboe, Comparative analysis of fluoride concentrations in groundwaters in northern and southern Ghana: implications for the contaminant sources. Earth Syst. Environ., vol. 1 no. 2, pp. 103-117, 2018.

[3] S.M. Yidana, B. Banoeng-Yakubo, T.M. Akabzaa, Analysis of groundwater quality using multivariate and spatial analyses in the Keta basin, Ghana. Journal of African Earth Sciences, vol. 58 no. 2 , pp. 220-234, 2010.

[4] V. Cloutier, R. Lefebvre, M.M. Savard, E. Bourque, R. Therrien, Hydrogeochemistry and groundwater origin of the BassesLaurentides sedimentary rock aquifer system, St. Lawrence Lowlands, Québec, Canada. Hydrogeology Journal, vol. 14 pp. 573 590, 2006. 
[5] V. Cloutier, R. Lefebvre, R. Therrien, M.M. Savard, Multivariate statistical analysis of geochemical data as indicative of the hydrogeochemical evolution of groundwater in a sedimentary rock aquifer system. Journal of Hydrology, vol. 353, pp. 294 - 313, 2008.

[6] M. Kumar, A.L. Ramanathan, M.S. Rao, B. Kumar, Identification and evaluation of hydrogeochemical processes in the groundwater environment of Delhi, India. J Environ Geol., vol. 50, pp. 1025 1039, 2006.

[7] B.T. Kamtchueng, W.Y. Fantong, M.J. Wirmvem, R.E. Tiodjio, A.F Takounjou, J.R. Ndam Ngoupayou, M. Kusakabe, O. Jing Zhang Takeshi, G. Tanyileke, J.V. Hell, A. Ueda, Hydrogeochemistry and quality of surface water and groundwater in the vicinity of lake Monoun, West Cameroon: approach from multivariate statistical analysis and stable isotopic characterization. Environ. Monit. Assess., vol. 188, pp. 1-24, 2016.

[8] K.S. Voudouris, N.J. Lambrakis, G. Papatheothourou and P Daskalaki, An Application of Factor Analysis for the Study of the Hydrogeological Conditions in Plio-Pieistocene Aquifers of NW Achaia (NW Peloponnesus, Greece). Mathematical Geology, vol. 29, pp. 43-59, 1997.

[9] M.S. Aboubacar, L. Xueyu, K. Sidi, Assessing groundwater mineralization process, quality, and isotopic recharge origin in the Sahel Region in Africa. Water, 11, 789, 2019.

[10] E.M.C. Ana, A.R.L. José, A.M.C. Diego, T.V. José, D.L.B. Josue, and M.R. Janete, Identification of the Hydrogeochemical Processes and Assessment of Groundwater Quality, Using Multivariate Statistical Approaches and Water Quality Index in a Wastewater Irrigated Region. Water, vol. 11, pp. 1702, 2019.

[11] A. Tonang Zebaze, Influence de la lithologie et des structures géologiques sur la dynamique et la qualité des eaux des aquifères de socle dans la région de Mbakaou et ses environs. M.S. Thesis, Department of Earth Science, Univ. Dschang, Cameroon, 2009.

[12] S.F. Toteu, W.R. Van Schmus, J. Penaye, A. Michard, New U-Pb, and Sm-Nd data from North-Central Cameroun and its bearing on the pre-Pan-African history of Central Africa. Precambrian Research, vol. 108, pp. 45-73, 2001.

[13] R. Tchameni, A. Pouclet, J. Penaye, A.A. Ganwa, S.F. Toteu, Petrography and geochemistry of the Ngaoundere Pan-African granitoïds in Central North Cameroun : Implication for thier sources and geological setting. Journal of African Earth Science, vol. 44, pp. 511-529, 2006.

[14] V. Ngako, P. Affaton, J.M. Nnange, T. Njanko, Pan-African tectonic evolution in central and southern Cameroon: transpression and transtension during sinistral shear movements. Journal of African Earth Sciences, vol. 36, pp. 207-214, 2003.

[15] M. Lasserre, Carte géologique de reconnaissance à l'échelle 1/500 000, territoire du Cameroun, Ngaoundéré-Est, Direction des Mines et de la Géologie, Yaoundé Cameroun, 1961.

[16] J.P. Nzenti, B. Kapajika, T.L. Warnen Ruanonza, Synkynematic emplacement of granitoid, in Pan-African shear zone in central Camroon. Journal of African Earth Science, vol. 45, pp. 74-86, 2006.

[17] T. Njanko, A. Nedelec, P. Affaton, Synkinematic high-K calcoalcaline plutons associated to the Pan-African central Cameroon Shear zone (W-Tibati area): petrology and geodynamic significance. Journal of African Earth Sciences, vol. 44, pp. 494-510, 2006.

[18] Souaibou, J. Mvondo Ondoua, A. Elimbi, J.E. Ekodeck, B.V. Kamgang Kabeyene, Caractéristiques morphologiques et géochimiques des manteaux d'altération développés sur granitoïdes dans la région de l'Adamaoua (Cameroun). European Scientific Journal, vol. 11, no. 15, pp. 187 - 204, 2015.

[19] T.W. Tchaptchet, P. Tematio, T.N. Guimapi, E. Happi, I. Tiomo, N.M. Momo, Morphological, mineral and geochemical characterization of soil profiles in Meïganga as tools for rock weathering intensity and trend evaluation and residual ore deposit prospection in the mineralized domain of central Cameroon. Geological society of London, vol. 22 pp. 1-25, 2020.

[20] A. Njueya Kopa, Apport des méthodes géophysiques et géostatistiques à la caractérisation électrique et structurale des aquifères du secteur Centre de la Chaîne Panafricaine d'Afrique Centrale au Cameroun: implication dans la réduction du taux d'échec des forages. Thèse de Doctorat/Ph.D, Département Sciences de la Terre, Université de Dschang, Cameroun, 2018.

[21] A. Tonang Zebaze, A. Njueya Kopa, M. Kwekam, E. Temgoua, Assessment of hydrogeoelectrical characteristics of crystalline aquifers and groundwaters quality in Adamawa plateau: case of Mbakaou (Adamawa - Cameroon). Environmental and Earth Sciences Reseach Journal, vol. 7 no. 4, pp. 153-163, 2020.
[22] World Health Organization (WHO), Guidelines for Drinking-Water Quality, WHO Press, 20 Avenue Appia, 1211 Geneva 27, Switzerland, ED-3, pp. 26-33, 2006.

[23] D.K. Chadha, A proposed new diagram for geochemical classification of natural waters and interpretation of chemical data. Hydrogeology Journal, vol. 7, no. 5, pp. 431-439, 1999.

[24] S. Kiymaz and U. Karadavut, Application of multivariate statistical analysis in the assessment of surface water quality in Seyfe lake, Turkey. Journal of Agricultural Sciences, vol. 20, pp. 152- 163, 2014.

[25] E.D. Sunkari, M. Abu, P.S. Bayowobie, U.E. Dokuz, Hydrogeochemical appraisal of groundwater quality in the Ga west municipality, Ghana: Implication for domestic and irrigation purposes. Groundwater for Sustainable Development, vol. 8, pp. 501-511, 2019.

[26] A. Nono, E. Temgoua, J.D.H. Likeng, T.J.P. Djoukouo, Influence de la nature lithologique et des structures géologiques sur la qualité des eaux souterraines sur le versant Nord des Monts Bambouto (Hautes terres de l'Ouest-Cameroun): cas du village Balepo et de ses environs. Africa Geoscience Review, pp. 149-162, 2008.

[27] A. Nono, J.D.H. Likeng, H. Wabo, Y.G. Tabue, S. Biaya, Influence de la nature lithologique et des structures géologiques sur la qualité et la dynamique des eaux souterraines et des sources dans les hauts plateaux de 1'Ouest-Cameroun. International Journal of Biological and Chemical Sciences, vol. 3, no. 2, pp. 218-239, 2009.

[28] A.A. Ako, J. Shimada, T. Hosono, M. Kagabu, A.R. Ayuk, G.E. Nkeng, G.E.T. Eyong, A.L.F. Takounjou, Spring water quality and usability in the Mount Cameroon area revealed by hydrogeochemistry. Environ. Geochem. Health vol. 34, no. 5, pp. 615-639, 2012.

[29] A.M. Piper, A graphic procedure in the geochemical interpretation of water analysis. Trans. Am. Geophys. Un. Papers, Hydrol., pp. 914929, 1944.

[30] B. Babita, M. Nandita, H.K. Sahoo, Interpretation of groundwater chemistry using Piper and Chadha's diagrams: a comparative study from Balangir and Puintala blocks of Blagir district, Odisha, India. Journal of Emerging Technologies and Innovative Research, pp. 3539, 2019.

[31] P. Ravikumar and R.K. Somashekar, Principal component analysis and hydrochemical facies characterization to evaluate groundwater quality in Varahi river basin, Karnataka state, India. Appl. Water Sci., vol. 7, pp. $745-755,2017$.

[32] H. Schoeller, Geochemistry of groundwater. In: Groundwater studies- An International Guide for Research and Practice. UNESCO, Paris, Ch., vol. 15, pp. 1-18, 1977.

[33] S. Gupta, P.S. Dandele, M.B. Verma, P.B. Maithani, Geochemical Assessment of Groundwater around Macherla-Karempudi Area, Guntur District, Andhra Pradesh. Journal Geological Society of India, vol. 73, pp. 202-212, 2009.

[34] R.J. Gibbs, Mechanisms controlling worlds water chemistry. Sc., vol. 170, pp. 1088-1090, 1970.

[35] Y. Jiang, Y. Wu, C. Groves, D. Yuan, P. Kambesis, Natural and anthropogenic factors affecting the groundwater quality in the Nandong karst underground river system in Yunan, China. $J$. Contam. Hydrol., vol. 109, pp. 49-61, 2009.

[36] M. Kumar, K. Kumari, A. Ramanathan, R. Saxena, A comparative evaluation of groundwater suitability for irrigation and drinking purposes in two intensively cultivated districts of Punjab. India $J$ Environ Geol., vol. 53, pp. 553-574, 2007.

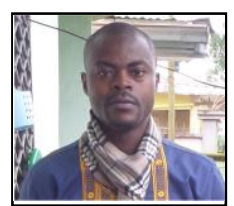

A. Njueya Kopa is a Ph.D holder in Hydrology and water management at the Earth Science Department in the Faculty of Science at the University of Dschang, Cameroon, 2018.

Dr. Njueya Kopa Adoua is a Lecturer at the University of Dschang, Cameroon. 